\title{
INS wt Allele
}

National Cancer Institute

\section{Source}

National Cancer Institute. INS wt Allele. NCI Thesaurus. Code C52420.

Human INS wild-type allele is located in the vicinity of $11 \mathrm{p} 15.5$ and is approximately $2 \mathrm{~kb}$ in length. This allele, which encodes insulin protein, plays a role in the modulation of both blood glucose levels and the process of glycolysis. Gene mutations are associated with familial hyperproinsulinemia. 